\title{
Soft news stories exchange between South and North of the Mediterranean Sea
}

Échanges d'actualités entre le Sud et le Nord de la Méditerranée

Intercambio de noticias entre el sur y el norte del Mar Mediterráneo

MEGARI Larbi and IZEDAREN Fayçal

(2) OpenEdition

Journals

Electronic version

URL: http://journals.openedition.org/ctd/2381

DOI: $10.4000 /$ ctd.2381

ISSN: 2491-1437

\section{Publisher}

Chaire Unesco Pratiques émergentes en technologies et communication pour le développement

Printed version

ISBN: 2491-1437

Electronic reference

MEGARI Larbi and IZEDAREN Fayçal, « Soft news stories exchange between South and North of the Mediterranean Sea », Communication, technologies et développement [Online], 7 | 2019, Online since 20 June 2019, connection on 09 December 2019. URL : http://journals.openedition.org/ctd/2381 ; DOI : $10.4000 /$ ctd. 2381

This text was automatically generated on 9 December 2019

Communication, technologies et développement 


\title{
Soft news stories exchange between South and North of the Mediterranean Sea
}

\author{
Échanges d'actualités entre le Sud et le Nord de la Méditerranée \\ Intercambio de noticias entre el sur y el norte del Mar Mediterráneo
}

MEGARI Larbi and IZEDAREN Fayçal

1 Cooperation in media and broadcast industry between Mediterranean countries is one of the most important partnerships between southern and northern sides of this basin ${ }^{1}$. Public broadcasting companies in this region are making this partnership a reality through their cooperation in this field. News industry is the most important part of this cooperation. Mediterranean public broadcasters are creating many forms of cooperation in the field of news video content, and one of these forms is news exchange which is a very important part of news production process in news industry today. As the news industry is getting bigger and more complicated, the act of cooperation and partnership in media industry became a separate specialty. This is what is called now news exchange.

2 The news exchange in broadcast industry is an activity that focuses on offering and receiving news video contents either for free or for money. This activity is done either on a bilateral basis (between two broadcasters) or on a multilateral basis through organizations working as intermediaries between broadcasters (including news agencies).

3 The subject of our current study is the exchange of soft news stories between public broadcasters in the Mediterranean Sea. We mean by "soft" news stories all the news items that are not on politics or economics or news stories that are hard breaking news. Within the context of this exchange that is taking place between Mediterranean countries, public broadcasters in these nations are offering to one another free news items (short videos with the duration of less than 5 minutes) to be used in their news bulletins and magazines and also in their many other programs formats. Usually these 
tasks (swapping news items) are done by a service called "News Gathering Desk" or "international News desk" or departments bearing other names.

4 Every year since 2002, the year in which the Algerian television took in charge the coordination of Mediterranean News Exchange, commonly known as ERNM, around 1000 soft news items are exchanged between the two sides of the Mediterranean basin. As part of a wider and more general news exchange monitored by the European Broadcasters Union (EBU), the flux of the Mediterranean news is mostly specialized in soft stories, namely culture, environment, traditions and many other topics, but which do not include political news or any other hard news.

5 The EBU is one of the most known distributors of sports and news content for the world's top broadcast and media platforms. Its headquarters is in Geneva, but it has bureaus in many other places including Russia and United States of America. It has also One Stop Shop (OSS) accredited everywhere across the world. OSS are communication services organizations that are located everywhere across the world. This OSS deals with broadcasters requests on the behalf of the EBU.

6 Also, this Mediterranean news exchange is being jointly monitored by the European Broadcasters Union EBU and the Permanent Conference of Mediterranean Audiovisual Operators (COPEAM), which is a non-profit international association devoted to the promotion of dialogue and cultural integration in the Mediterranean region, throughout the involvement of the major actors of the audiovisual sector, among which the public service radio and TV broadcasters from 26 countries in the area, besides professional and cultural associations, institutions, higher education institutions and specialization structures, independent producers and local authorities of Europe, Balkans, North Africa and Middle East. Alongside the EBU and the COPEAM, the Arab States Broadcasters Union (ASBU) ${ }^{2}$ is taking part in this monitoring and does participate via its members in this news exchange.

\section{Research question}

7 Our study is a comparison between the participation of countries from the north of Mediterranean Sea and the participation of countries from the south in this news exchange. The comparison will be focusing on the quantity of soft news items coming from each side of the Mediterranean Sea. In other words, we will try to determine which side, North or South, is offering more soft news items.

Our comparison goes beyond the quantitative aspect. It also focuses on the nature of items offered by the two sides of the Mediterranean Sea. In other words, what, for example, southern and northern countries, around the Mediterranean Sea, are offering most? Which countries are focusing more on what kind of news? Are southern countries focusing more on politics or culture or other topics? And what northern countries are offering most?

\section{Sample and scope of the study}

9 Our sample includes soft stories items exchanged between the Mediterranean countries within the regional news exchange ERNM. We have gathered statistics of exchanged soft stories items that took place between the $1^{\text {st }}$ of January and the $31^{\text {st }}$ of March of the 
year 2017. We have made a random choice of the period. Our source of these figures is the official website ${ }^{3}$ of the EBU, which is a working place for the EBU members.

During this period of time, 311 soft news items have been exchanged between 10 Mediterranean countries, 5 countries from each side. It happened that the countries which have participated and offered soft news stories in this randomly chosen period of time are these ten countries :

North of the Mediterranean Sea : Portugal, Spain, France, Croatia and Italy.

oxchange are state owned broadcaster, be it in the South of the Mediterranean Sea or in the North, and this choice (the sample being news items produced and offered by state owned broadcasters) can be explained by three reasons :

The first reason is the availability of the data. These statistics were made available to us thanks to the fact that one of us happens to be the Head of the Mediterranean News Exchange and the Head of News and Magazine Commission of the COPEAM, which was behind the creation of this exchange in the first place.

15 The second reason for our choice is that by choosing state owned broadcasters only, we are here limiting the scope of our research to the official version (public version) of the Mediterranean news exchange that is by far wider than the public exchange that we are focusing on in this current study. In other words, we have excluded any Mediterranean news exchange that has been done by private sectors.

16 Another benefit from our choice (third reason) is that we are eliminating the "economic factor". Public broadcasters produce or select news items to be offered without spending money. These broadcasters are not producing these news stories exclusively for the exchange, but for their news bulletins, which means they are producing these news without taking into consideration their participation in the exchange, so there will be no financial limitation that could influence their choice of offered items, hence no financial factor would be taken into consideration in our findings analysis.

\section{Methodology}

17 We have adopted a quantitative approach to our sample. We compared the number of soft news stories offered by southern countries to the number of the same kind of news (soft news stories) offered by the North.

We have also looked into the content of these soft news stories. According to the editorial line of the News Mediterranean Exchange ERNM, in this exchange, members are invited to share news items concerned with culture, arts, traditions, heritage, environment, society and so on. In other words, this exchange has been created for what is commonly called in news industry "soft news stories". Other kinds of news stories, commonly called "Hard news Stories", or other breaking news stories, have their own exchange within the EBU. This exchange is called EVN, and EVS for Sports news.

19 We have also used one of the most recent technologies of satellite signal monitoring that is available at the European Broadcasters Union (EBU) in Geneva, which is the 
Watermarking monitoring system. The watermarking technology helps monitor the use by broadcasters, everywhere across the world, of the EBU news items that have been offered from this organization's members or its associates or its organizations sisters. ${ }^{4}$ Once the news item, any news item, goes through the EBU watermarking system, the signal of this item will be given a particular digital finger-print, so it will be located and monitored whenever this signal goes on air. At the end of the day, all Eurovision used news items by any given broadcaster, will be registered in EBU monitoring fact sheets, stating which broadcaster has used which item and when. And here where we came in : we have collected these data and put them in a simple table.

Our use of these data is to see which news items are mostly used by broadcasters. This will inform us which countries are offering the most used soft news items. The analysis of these data can help us understand which side of the Mediterranean is more successful in offering news that is being used more frequently by Mediterranean broadcasters and also by non-Mediterranean companies. We need to mention here that in news exchange field, when you offer a news item; this does not necessarily mean this story will be used by broadcasters.

\section{How we collected our data}

21 We have manually gathered our statistics from the EBU mentioned website, using advanced research tool (available on the website) that gives you the possibility to narrow your research down to exactly what you are looking for: Stories exchanged as Mediterranean News Exchange (ERNM), between the $1^{\text {st }}$ January and the $31^{\text {st }}$ March 2017.

Concerning the statistics in relation to news item used by broadcasters, we have simply made a plain request to EBU, which kindly answered by sending us an Excel document containing very useful data for our research, in addition to some data that our research was not concerned with.

\section{Findings}

After collecting our statistics using the methods that we have mentioned earlier in this article, we have created a simple table that shows the number of news items, offered from each side of the Mediterranean Sea (figure 1).

As we can read from the table (figure 1), we can easily see the huge difference in terms of quantity of offered news items between northern and southern countries of the Mediterranean Sea. During the first three months of 2017, from the north of the Mediterranean Sea, Croatia, Portugal, Spain, France and Italy, put together, have offered only 52 news items to the exchange. From the southern side of this basin, Algeria, Morocco, Tunisia, Turkey and Jordan, put together, have offered during the same period more than 250 items (259 news items exactly).

\begin{tabular}{|l|l|}
\hline Mediterranean regions & Number of news items \\
\hline South of Med. & 259 \\
\hline
\end{tabular}


North of Med. 52

Figure 1. Contribution by region (South vs North).

Reading the table above, we have noticed that Morocco public broadcaster alone has offered more news items (136 news items) during this particular period than all northern countries put together (52 news items only). In other words, MASNRT (Morocco public broadcaster) has offered three times what northern countries have offered.The Algerian public broadcaster also offered almost the same number (57 news items) that has been offered by northern countries put together (figure 2).

\begin{tabular}{|l|l|}
\hline Country & Number of news items \\
\hline Morocco & 136 \\
\hline Algeria & 57 \\
\hline Turkey & 43 \\
\hline Tunisia & 20 \\
\hline Jordan & 03 \\
\hline Total of South contribution & 259 \\
\hline Croatia & 26 \\
\hline Italy & 14 \\
\hline Portugal & 06 \\
\hline Spain & 05 \\
\hline France & 01 \\
\hline Total of North contribution & 52 \\
\hline
\end{tabular}

Figure 2. Contribution by country.

\section{Degree of commitment to editorial line of the Mediterranean News Exchange}

One of our most important findings from our collected data is that there is a huge difference between the contributions from the two sides of the Mediterranean Sea in terms of their commitment to the well-defined editorial line of this soft news exchange.

27 As we have already stated earlier in the current article, the Mediterranean news exchange is meant to be a space for footage of soft stories only, and to be far away from 
hard news. In other words, this news exchange is for news items that are exclusively concerned with arts, culture, tourism, environment, tradition, festivals, religious occasions and so on. But on the ground, we have noticed that this rule has not been fully respected by the Mediterranean news exchange.

We have also noticed that the degree of the non-respect of the ERNM editorial line is not the same from both sides. We have noticed that the northern countries are, by far, more committed to the editorial line of this Mediterranean exchange than the countries from the southern side of the Mediterranean Sea (figure 3, figure 4).

\begin{tabular}{|c|c|c|c|c|c|}
\hline Genre/Country & Morocco & Algeria & Turkey & Croatia & Tunisia \\
\hline Culture & 15 & 14 & 27 & 12 & 11 \\
\hline Economics & 29 & 9 & 1 & 5 & \\
\hline Cooperation & 28 & 14 & 2 & & 2 \\
\hline Politics & 19 & 5 & 2 & & 4 \\
\hline Tourism & 15 & 2 & 6 & 3 & 2 \\
\hline Hard news & 17 & 1 & 2 & 1 & 1 \\
\hline Social & 4 & 9 & & 2 & \\
\hline Environment & 8 & 2 & 3 & 3 & \\
\hline Religion & 1 & 1 & & & \\
\hline Total & 136 & 57 & 43 & 26 & 20 \\
\hline Genre/Country & Italy & Portugal & Spain & Jordan & France \\
\hline Culture & 8 & 4 & 1 & 1 & 1 \\
\hline Economics & 2 & & 1 & 2 & \\
\hline Cooperation & & 1 & & & \\
\hline Politics & & 1 & 1 & & \\
\hline Tourism & 2 & & 2 & & \\
\hline \multicolumn{6}{|l|}{ Hard news } \\
\hline \multicolumn{6}{|l|}{ Social } \\
\hline Environment & 2 & & & & \\
\hline \multicolumn{6}{|l|}{ Religion } \\
\hline Total & 14 & 06 & 05 & 03 & 01 \\
\hline
\end{tabular}


Figure 3. Offered news items selected by Genre/Country.

\begin{tabular}{|l|l|l|}
\hline Genre & North & South \\
\hline Culture & 26 & 68 \\
\hline Economics & 08 & 41 \\
\hline Cooperation & 01 & 46 \\
\hline Politics & 02 & 30 \\
\hline Tourism & 07 & 25 \\
\hline Hard news & 01 & 20 \\
\hline Social & 02 & 14 \\
\hline Environment & 05 & 13 \\
\hline Religion & 00 & 02 \\
\hline Total & 52 & 259 \\
\hline
\end{tabular}

Figure 4. Offered news items selected by Genre/Region. (out of their 52 offered news items) which are not soft stories (politics and hard news items), that is less than $6 \%$ of their entire offered news items. On the other hand, southern countries contribution to this news exchange is far away from its editorial line. In numbers, southern members of the ERNM exchange have offered some 50 news items that do not respect the editorial line of the exchange (30 news items about politics, and 20 news items about hard news), that is almost $20 \%$ of the entire offered items to the exchange during the first three months of the year 2017 (figure 4).

A country like Morocco is on the top of southern countries that are not sticking to the editorial line of this exchange. The MASNRT (the official state owned broadcaster) has alone offered 36 news items that do not fit within the Mediterranean news exchange editorial line (19 news items on politics and other 17 hard news items). According to figures shown in table "figure 3", more than $26,4 \%$ of Morocco offers are out of ERNM scope.

\section{Use of Mediterranean news items by broadcasters}

Using Watermarking technology provided by EBU in Geneva, we were given access to valuable statistics containing the number of uses of soft news items by various broadcasters. These figures informed us on the usefulness of these news items for Mediterranean broadcasters and also for non-Mediterranean broadcasters. ${ }^{5}$ 


\begin{tabular}{|l|l|}
\hline Med Northern Countries & Number of items uses \\
\hline Italy & 207 \\
\hline Portugal & 42 \\
\hline France & 26 \\
\hline Croatia & 21 \\
\hline Spain & 14 \\
\hline Total & 310 \\
\hline Med Southern Countries & Number of items uses \\
\hline Morocco & 116 \\
\hline Turkey & 104 \\
\hline Algeria & 13 \\
\hline Tunisia & 12 \\
\hline Jordan & 00 \\
\hline Total & 555 \\
\hline Total of all uses & 245 \\
\hline
\end{tabular}

Figure 5. Uses of Med news items.

32 As clearly shown in the table (figure 5), news items coming from the north are, by far, more used by broadcasters than news items coming from the southern countries of the Mediterranean Sea. We need to remember that taking into consideration the number of offered items from both sides will make the difference between the usefulness of news items clearer.

Mediterranean countries from the North have offered only 52 news items during the first three months of 2017, but the number of their uses is 310 times, whereas the countries in the South of the Mediterranean basin have offered 259, but the number of their items' uses is 245 only, which is by far lower in terms of uses achieved by items coming from the North. The Italian Television ITRAI, alone, has achieved almost the same number of uses of all southern broadcasters' items put together (207 uses for ITRAI broadcaster against 245 uses for the southern countries).

Although the northern countries have offered less than $20 \%$ of the total offered news items in the Mediterranean region (The North with 52 news items against the South with 259 news items), we can notice that broadcasters from the North have achieved more than $55 \%$ from the total uses of the entire uses of the Mediterranean countries (The North with 310 uses against the South with 245 uses only). 


\section{Conclusion} broadcasters are not sticking to Mediterranean news exchange rules, so they have included, as we have seen in our findings, their politics and hard news stories into the exchange, and this makes their offers look bigger than the offer from the North. This can be explained by the fact that southern countries are using this news exchange space for their political propaganda. In the Arab world, state owned media is considered one of the most important tools that governments should use to justify their political agenda (Kent, Palmer, 2005). For example, the Moroccan television has offered more than 20 news items (out of the total of its 97 news items offered to the exchange during the first three months of the year 2017) on the activities of King Mohammed VI, and more news items on the political activities of the government and its ministers. Another example to prove that these countries are using this exchange for political propaganda is the public broadcaster of Jordan. This country has offered 2 of its three offers on the royal family and its activities.

\section{Religion : A taboo or a mere coincidence?}

Although the Mediterranean region is rich in terms of religious diversity, offers related to religion come at the bottom of the offered news items list, with only 02 items (less than $1 \%$ of the global number). It is also useful to mention that both offers came from the southern countries of the Mediterranean basin. As we know that religious content is really important for Arab countries ${ }^{6}$, we, at first, wondered why there are no big offers on this topic. We also know that both sides of the Mediterranean Sea witness every year many religious occasions and festivals such as Ramadan, the two Eids of

Communication, technologies et développement, 7| 2019 
Muslim populations (one immediately after the sacred month of Ramadan and the second one, Adha Eid, right after the Hajj), Christmas and Easter for Christian populations, Ashura for Shia Muslims in particular, even if it is also celebrated by Sunni populations. But we looked again into the chosen period of the year that was the subject of our study, which is the three months (January, February and March), and we found out that this particular period of time does not include these religious occasions and festivals.

\section{Cultural imperialism : the Mediterranean version}

The well-known theory of "Cultural Imperialism", argues that the west is flooding the South (including the East) with cultural contents, including media contents. According to the same idea, these cultural contents are "westernizing" the South, as part of the westernization of the Third World". Is "Cultural Imperialism" theory valid within the Mediterranean context? The answer is no. According to our statistics, the southern parts of the Mediterranean Sea are flooding the North with its video contents. According to our figures, the Mediterranean news exchange does not reflect what the "The New International Order of News" suggests. If there is any cultural imperialism, then it is in the opposite direction : from South to North.

\section{BIBLIOGRAPHY}

\section{Reference list}

Crivello M., 2013, «L'émergence et l'élaboration d'un patrimoine télévisuel en Méditerranée », Sociétés et représentations, 35, pp. 97-107.

Guaaybess T., 2013, «Les bouquets satellitaires et le développement du système télévisuel arabe ». URL : https://www.inaglobal.fr/television/article/les-bouquets-satellitaires-et-le-developpement-dusysteme-televisuel-arabe.

Guaaybess T., Télévisions arabes sur orbite: Un système médiatique en mutation (1960-2004), 2005, Paris, CNRS.

Kent G., Palmer J., 2005, « Mondes arabophones et médias », Questions de communication, 8, pp. 7-16.

Mattelart T., 2002, « Le Tiers Monde à l'épreuve des médias audiovisuels transnationaux : 40 ans de controverses théoriques ", in Mattelart T., La mondialisation des médias contre la censure, Paris, De Boeck, pp. 17-80.

Mattelart T., 2017, « Nécessaire rééquilibrage des flux d'information transnationaux », in Bertrand Badie B., Vidal D., dirs., En quête d'alternatives, L'état du monde 2018, Paris, La Découverte, pp. 31-39. 
The official website of the Arab States Broadcasters Union. URL : www.asbu.net.

The official website of the European Broadcasters Unions (EBU). URL : www.eurovision.net.

The official website of the Permanent Conference of Mediterranean Audiovisual Operators

(COPEAM). URL : http://www.copeam.org.

\section{NOTES}

1. Crivello, 2013 : 97-107.

2. Arab States Broadcasters Union called ASBU is an organization gathering all Arab states public broadcasting corporations. This union is part of the League of Arab States. The news exchange centre of this union is located in Algiers, whereas its administration is located in Tunis.

3. URL: www.eurovision.net.

4. EBU has many levels of partnership: members with full membership, associate members and independents organizations sisters such as AsiaVision (news exchange of Asian countries).

5. Watermarking statistics that we were given access to do not include information regarding which broadcaster has used which items.

6. Guaaybess, 2010.

7. Mattelart, 2002.

8. Mattelart, $2017: 31-39$.

\section{ABSTRACTS}

Dans cette étude, nous nous sommes penchés sur la nature du flux d'informations partagées entre 10 pays méditerranéens par l'intermédiaire de leurs sociétés publiques de diffusion. Nous avons choisi 5 pays du nord de la mer Méditerranée et 5 autres pays du sud. Cet échange de nouvelles a eu lieu dans le cadre de l'échange d'informations méditerranéen, qui fait partie du principal échange d'informations suivi par l'Union Européenne des Radiodiffuseurs (UER).

En este estudio, hemos analizado la naturaleza del flujo de noticias blandas que han sido compartidas entre 10 países mediterráneos a través de sus corporaciones de radiodifusión pública. Hemos elegido 5 países del norte del Mediterráneo y otros 5 países del sur. Este intercambio de noticias tuvo lugar en el marco del intercambio de noticias del Mediterráneo, que forma parte del principal intercambio de noticias supervisado por la Unión Europea de Radiodifusores (UER). 
INDEX

Mots-clés: Actualités, échanges méditerranéens, informations magazines.

Keywords: In this study, we have looked into the nature of the flux of soft news stories that have been shared between 10 Mediterranean countries via their public broadcasting corporations. We have chosen 5 countries from the northern side of the Mediterranean Sea, and other 5 countries from the south. This news exchange took place within the Mediterranean news exchange that is part of the main news exchange monitored by the European Broadcasters Union (EBU).

Palabras claves: Noticias, intercambio mediterráneo, historias blandas.

\section{AUTHORS}

\section{MEGARI LARBI}

Doctorant en Sciences de l'information et de la communication, Pratiques et Ressources de l'Information et des Médiations (P r i m), Université de Tours

\section{IZEDAREN FAYÇAL}

Maître de conférences en sociologie, LAPSSES, Laboratoire de recherche en activités physiques et sportives, Société - Education - santé, Université Hassiba Ben Bouali - Chlef, Algérie 